\title{
THE ROLE OF CHAMBER SYSTEM IN DEVELOPMENT OF AGRICOMMERCE IN SERBIA
}

\author{
Emil Cukic
}

\author{
Belgrade Chamber of Commerce, Serbia Agriculture and Food Industry Association
}

\begin{abstract}
This research is carried out in order to be determined the role of Chamber system in development of agricommerce along with successful preparation of Serbia for EU accession.

On February 28, 1857 Prince Aleksandar Karaðorðeviæ signed the Decree, called THE CONSTITUTION OF THE TRADE. By this Decree, the first Business Association in Serbia was constituted.

Under the Law on retail stores passed in June 1910, the first chambers were established. Those were the following:

- The Chamber of TRADE

- The Chamber of CRAFTS

- The Chamber of INDUSTRY

- The Chamber of WORKERS

Today, in conditions of economic and social reforms and transfer toward market oriented economy, chambers in Serbia chose to reconsider their role, by using experiences of chambers in countries with developed market economy. The chamber strives to be organized as independent, business oriented and expert association of economic operators.

The structure of economy, from the aspect of important economic indicators (total revenue, profit), shows dominant share of manufacturing and agro-industry, trade, financial and other services sectors, transport, telecommunication, and construction industries. By generating over $30 \%$ of GDP and employment, Belgrade plays vital role in the economy of the whole Serbia. That is an advantage, but also the responsibility to constantly stimulate faster development and higher living standards by inciting the positive changes in economic and overall environment.
\end{abstract}

Key words: chamber structure, coordination, institutions, advocate

\section{Introduction}

Chamber of Commerce is organized as vocational association and its main goals are quality services and assistance to its member companies as well as proper representing of their interests.

Members of the Chamber of Commerce are all legal and private entities that perform their registered business activity on the territory of Serbia, no matter what the type of ownership it is.

Chamber, through its branch Associations and Boards, Assembly and Managing Board, represents interests of its member companies and monitors and analyzes economic development. It influences adoption of economic policy measures, monitors their effects and suggests corrections if necessary. The Chamber provides expert assistance to its member companies in solving concrete problems, affirmates and promotes their production programme at trade fairs and exhibitions, in the country and abroad. By networking economic operators with foreign partners through contacts with foreign chambers of commerce, embassies, etc. it has important role in transition process of social and economic system of the country. That way, our companies return to foreign markets and revive production and economic growth, by mobilizing all creative powers in view of faster and more efficient economic recovery and easier adjustment to new business environment. A chamber provides assistance to its members in adapting to modern trends of market economy and in overcoming of the existing difficulties. Long lasting aim in the future will be creation of healthy, priphitable, modern and market oriented economy.

The chamber is actively involved in the activities regarding EU accession, by providing information to its members about this topic. By developing partnerships (with domestic and foreign institutions and organisations), chamber, as important instrument, participates in numerous projects financed by the EU, which makes significant contribution to social and economic development of the region. Within these activities it is important to mention cooperation of the chambers of commerce with NGOs as well.

Chambers of commerce cooperate with republic and regional institutions, representatives of foreign chambers of commerce in the country, scientific and research institutions and faculties as well as local self-government.

\section{Belgrade Chamber of Commerce}

Belgrade, capital of the Republic of Serbia and center of the South-East Europe, has significant potential in all areas that earn the attribute of a modern city, attractive for living 
and working in it. With approximately 1.8 million population ( $21 \%$ of Serbia's total) and over 600,000 employed, Belgrade is not only the seat of government and public institutions, but also a tourist, trade, industrial, transportation, financial, cultural, scientific, and educational centre.

The territory of the City of Belgrade is divided into 17 municipalities: 10 central (Čukarica, Voždovac, Vračar, Novi Beograd, Palilula, Rakovica, Savski venac, Stari grad, Zemun, Zvezdara) and 7 suburban (Barajevo, Grocka, Lazarevac, Obrenovac, Mladenovac, Sopot, and Surčin).

Economic potential of Belgrade constitute most of all 36,537 registered companies $338.3 \%$ of all Serbian companies) and 40,688 entrepreneurs (19.7\% of Serbia's total).

Due to the macroeconomic stability, market size, human resources, information technology, telecommunication and, especially, its geographic position and well-developed investment infrastructure, Belgrade became one of the most attractive locations for doing business in the region. In the competition for the European cities and regions of the future organized by the "Financial Times", in March 2006 Belgrade was awarded the title "City of the future in Southern Europe".

Belgrade Chamber of Commerce was founded and began working in January 1962.

Belgrade Chamber of Commerce is a true representative of economic operators which, in compliance with the economic development strategy, actively contributes to economic and social development and higher living standards, that should promote Belgrade to a leading position in the south-Eastern Europe.

The main activities of the Belgrade Chamber of Commerce, that is, services it offers to its members are as follows:

$\square$ REPRESENTING INTERESTS OF BELGRADE COMMERCE IN FRONT OF STATE AUTHORITIES AND INSTITUTIONS

- Initiating measures of fiscal, credit and monetary politics and total economic and legal regulations, in order to build-up market economy institutions;

- Defining of economic and system regulations and measures of economic policies;

- Creation of strategy of economic development of Belgrade region and Republic of Serbia and

- Sector and branch strategies

口 THE PLACE OF GATHERING, COMMUNICATION AND COOPERATION WITH LOCAL AND INTERNATIONAL BUSINESSPEOPLE - Networking and creation of solid business relations

- PROVIDING EDUCATION OF EMPLOYEES AND OTHER INDIVIDUALS IN ALL SECTORS AND ISSUE APPROPRIATE CERTIFICATES

口 PROVIDING INFORMATION AND CONSULTANT AND OTHER EXPERT SERVICES

- All kinds of statistical data and analyses

- Information on loan offer, development programs, innovations and patents offer, support programs for development of SME and entrepreneurship, particularly those financed by the funds
- Information on all current issues related to the business operations (business cooperation, application of laws, custom procedures, contracts)

- Address data on business entities, data from all the registers of general associations

- Assistance in registration of business entities and business plans elaborating

- Implementation of directives and standards necessary for business transactions with EU, CEFTA and other markets

- Consultant services related to the use EU funds (information, application, implementation, Project Management seminars and trainings

口 BUSINESS IMPROVEMENT THROUGH PROMOTIONS AND PRESENTATIONS

a PRESERVING GOOD BUSINESS CUSTOMS, PROTECTION OF BUSINESS ETHICS AND DEVELOPMENT OF SOCIAL RESPONSIBILITY.

\section{Association of Agriculture and Food Industry (AAFI)}

The Association is the basic form of organization and work within the Chamber. The Association is a form of organization and work for the Chamber members linked by their functions and branches.

The following associations are operate within the Chamber:

1. Association of Industry

2. Association of transportation and telecommunications

3. Association of Commerce

4. Association of civil engineering and public utility services

5. Association of agriculture and food industry

6. Association of catering and tourism

7. Association of banks, insurance organizations and other financial organizations

8. Association of informational activities

Agriculture plays an exceptional role in overall economic development of Serbia today, especially in reform and transition processes.

Table 1. The share of Agriculture and Food Industry in total GDP of The Republic of Serbia

\begin{tabular}{|c|c|c|c|}
\hline Year & Agricultural production & Food industry & Other \\
\hline 2002 & $14.8 \%$ & $5.9 \%$ & $79.3 \%$ \\
\hline 2003 & $13.6 \%$ & $5.7 \%$ & $80.7 \%$ \\
\hline 2004 & $15.0 \%$ & $5.4 \%$ & $79.6 \%$ \\
\hline 2005 & $13.5 \%$ & $5.4 \%$ & $81.1 \%$ \\
\hline 2006 & $12.6 \%$ & $5.3 \%$ & $82.1 \%$ \\
\hline 2007 & $10.8 \%$ & $5.2 \%$ & $84.0 \%$ \\
\hline 2008 & $11.8 \%$ & $5.5 \%$ & $82.7 \%$ \\
\hline 2009 & $10,8 \%$ & $7,2 \%$ & $82,0 \%$ \\
\hline
\end{tabular}

Source: Statistical Bureau of Republic of Serbia 
Agriculture and food industry with around 20\% share in GDP represent the major economic sector in the Republic of Serbia.

This sector will continue to have important effect on the economic developments in Serbia.

The activities of the AAFI are focused on realisation of the goals and tasks defined in the yearly Plan of Activities of the Chamber and of the AAFI, as well as of those set out during the year at the meetings of the Association Board, Chamber, and relevant Belgrade and Serbian institutions.

These activities are primarily carried out through the meetings of the Association Board, and meetings with representatives of companies and other stakeholders. In large number of topics and issues dealt with, there was a close cooperation with the Belgrade Union of Cooperatives.

Developments in the industry and performance of companies were monitored and analyzed on regular basis, as were the effects of economic policy measures, operating conditions, privatization and restructuring, and common problems in agriculture and food industry.

The special attention was focused on monitoring of new system solutions that should be in compliance with the Strategy for Development of Agriculture in Belgrade until 2015 and that concern measures for stimulation of agricultural production, subsidies in agriculture, system of reserves, agricultural land reform, production of safe food, environmental protection, and assistance in placement of goods and equal market access opportunities.

The AAFI was regularly analysing the terms of loans for agricultural and food producers and disseminating such information to companies and registered farms.

Process of privatisation was closely monitored and analyzed at the Board meetings. Differentiation of land ownership and privatisation of big agricultural companies were the most sensitive issues, especially the latter due to large amount of land in their possession and fact that it constitutes the reproductive base for agriculture.

In addition to the above, the AAFI was also engaged in finding solutions for contemporary problems identified by its members, other institutions and subjects.

The AAFI actively participated in activities of the Serbian Chamber of Commerce, Serbian Union of Cooperatives, Ministry of Agriculture, Belgrade City Administration Secretariat of Economy, Belgrade Institute of Statistics and Informatics, Faculty of Agriculture of the Belgrade University, and others.

\section{Conclusion}

Chambers of commerce face enormous challenge today to maintain but also to improve the present positions in their respective national economies. Main reasons for slow modernization of chambers of commerce are:

- absence of in-depth, long-term strategy for economic development on national and local levels;

- no balance between daily activities and engagement on strategic projects;
- resistance to essential, system-related changes;

- total absence or partial implementation of the principle of direct profitability from work;

- inherited image of chambers of commerce as "para-governmental" institutions (especially in the transition countries).

As for the system of chambers of commerce in Serbia, it is evident that the legislation in force does not prevent reforms in the chamber system, but the process has not started yet - neither from the outside, by the government, nor from within the chamber system itself. The reasons for that are twofold: "preoccupation" of the government by other issues on one hand, and on the other - "autism" of chambers, with stiff inner structures opposing any changes and thus missing out the chance to impose themselves as a real representative and service to companies which is, in fact, the essence of the European partnership recommendation - „to simplify the complex chamber system“.

From the contemporary chamber of commerce, especially those in the transition countries, it is expected:

- to advocate efficiently the needs and interests of its members in a dialogue with the government,

- to be an equal partner to the government in creation of business environment and economic policy measures that will stimulate economic development,

- to provide the requested services to its members.

Every country that wants to have a fair share in the business world today must have chambers of commerce that will communicate with the chambers of commerce in the countries that have well-developed market economy. Chambers have to be trustworthy institutions, with credentials based on their own capacities and professionalism that can respond adequately to all requirements of their members.

Chambers of commerce do not have invested in them any executive powers, nor should they. Instead, they must have strong arguments. Those arguments are knowledge, experience, information, and readiness and willingness to use all of them for the benefit of economy. Chambers of commerce must become equal, strong and capable partner of the government, always having in mind the primary interests of the economy and economic operators they represent. Complete political neutrality of chambers of commerce is essential because that is a precondition of professional authority and partnership with all those in power. The role of chambers of commerce can be especially important in the transition countries, but only when all the above has been in place.

Important role of the Serbian network of chambers of commerce in future is to promote the Serbian economy through cooperation with the investors already present in Serbia, participation in trade fairs and cooperation with chambers of commerce in foreign countries. By promotion and implementation of CEFTA Agreement and Free Trade Agreement with the Russian Federation, Serbia has become an attractive destination for foreign partners. That opens new possibilities for foreign market access. In conditions of transition and transformation into market-based operation, 
chambers of commerce have the advantage of being a system with long tradition and representative membership that advocates and protects interests of its members.

Only unbiased, efficient and modern chambers of commerce system is capable of sustaining the challenges of present economic developments and contributes to development of stimulating business environment.

\section{References:}

***** (2007): 150 Years of Tradition, Belgrade Chamber of Commerce, Belgrade.
***** (2008): Activity Report of the Serbian Chamber of Commerce, Serbian Chamber of Commerce, Belgrade.

Pavličevič M., Jevtič R. (2007): Serbian Chamber of Commerce 1857-2007, Serbian Chamber of Commerce, Belgrade.

Ranðelovič V. (2001): Economics of Agriculture and Cooperatives, Faculty of Agriculture, Zemun.

Mr Janoš Varga (2006): HACCP and Food Safety, Adižes, Novi $\mathrm{Sad}$

PhD Vlade Zarič (2008): Analysis of competitiveness of agricultural and food products from Serbia, Faculty of Agriculture, Zemun

Mr Vladimir Meðak (2008): Economic guide for the Stabilization and Association Agreement, ISAC Fond, Belgrade. 